\title{
Experimental Study on the Effect of Slag Powder on Performance of Double Liquid Grouting Material
}

\author{
Yanfang $\mathrm{Li}^{\mathrm{a}}$, Hongliang Huang ${ }^{\mathrm{b}}$ and Lijun Qiu ${ }^{\mathrm{c}}$ \\ Hebei University of Architecture, Zhangjiakou 075000, China

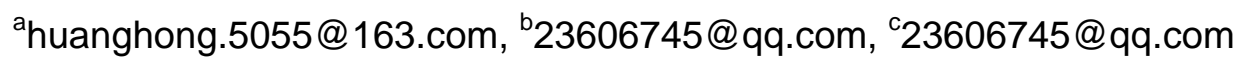

Keywords: Slag powder, Grouting material, Gel time, Consolidation strength, Experimental study

\begin{abstract}
On the premise of fixed cement slurry consistency and sodium silicate concentration, adjust the content of slag powder design 8 groups of ratio, cement and sodium silicate double liquid grouting material mix design and test research, through the collation and analysis of experimental data, obtained the influence of slag powder on cement-sodium silicate double liquid grouting materials gel time and consolidation strength of relationship.
\end{abstract}

\section{Introduction}

With the rapid development of grouting material composition in foundation reinforcement, construction technology and the use of performance, hazards of collapsible loess has been regarded more and more. The subject of the study of cement-sodium silicate double liquid grouting material (i.e. C-S double liquid grouting material), which is one of the advanced grouting materials commonly used in foundation reinforcement of construction engineering. It is one of cement, sodium silicate as the main agent (if necessary, adding additives), will both proportionally and respectively pumping mixed after injection of grouting process of formation.

\section{Test Raw Materials}

This topic mainly used in the test of raw materials and its basic performance parameters(Table 1).

Table 1 Test materials

\begin{tabular}{lll}
\hline $\begin{array}{l}\text { Name of raw } \\
\text { material }\end{array}$ & Manufacturer & The basic performance parameters \\
\hline $\mathrm{P} \cdot \mathrm{O} 42.5$ cement & Zhangjiakou jinyu cement co., LTD & $\begin{array}{l}3 \mathrm{~d}: \mathrm{f}_{\mathrm{tm}}=5.0 \mathrm{MPa}, \mathrm{f}_{\mathrm{c}}=23.8 \mathrm{MPa} \\
28 \mathrm{~d}: \mathrm{f}_{\mathrm{tm}}=8.0 \mathrm{MPa}, \mathrm{f}_{\mathrm{c}}=47.0 \mathrm{MPa}\end{array}$ \\
$\begin{array}{l}\text { Sodium silicate } \\
\text { Slag powder }\end{array}$ & Zhangjiakou qiaoxi yongsheng chemical plant & Modulus $\mathrm{n}=2.8$, baume degree ${ }^{0} \mathrm{Bé}=37$ \\
\hline
\end{tabular}

\section{Experimental Study}

Test Plan. Based on the comprehensive consideration that fluidity requirements of cement-sodium silicate grouting material, technical economy and high water cement ratio have effects on the consolidation strength of grouting material, water cement ratio (W/C) was designed as 0.8 in this test experimental study, sodium silicate grout baume degree ${ }^{0}$ Bé is set as 21,25 , sodium silicate grout volume that 1 times the volume of cement slurry, combined with the actual situation of the local resources, the admixture of slag powder were set as cementitious material quality $10 \%, 15 \%, 20 \%, 25 \%$, four volume, the ratio of combined into 8 groups of experimental research.

The Experimental Data. Tests of adding slag powder C-S double liquid grouting material of design of mixture ratio l(Table 2), determination of gel time and consolidation strength l(Table 3 and table 4). 
Table 2 Proportion of double fluid grouting material that add admixture

\begin{tabular}{llllll}
\hline \multirow{2}{*}{$\begin{array}{l}\text { Cooperate with the } \\
\text { serial number }\end{array}$} & The ratio of number & \multicolumn{2}{l}{ Slurry $(1000 \mathrm{ml})$} & $\begin{array}{l}\text { Sodium silicate } \\
(\mathrm{ml})\end{array}$ & $\begin{array}{l}\text { Slag } \\
\text { powder(g) }\end{array}$ \\
\cline { 3 - 4 } & & Cement $(\mathrm{g})$ & Water $(\mathrm{ml})$. & 1000 & ---- \\
H09 & C8V1.0S21+N & 900 & 720 & 1000 & 90 \\
H57 & C8V1.0S21+K10 & 810 & 720 & 1000 & 135 \\
H58 & C8V1.0S21+K15 & 765 & 720 & 1000 & 180 \\
H59 & C8V1.0S21+K20 & 720 & 720 & 1000 & 225 \\
H60 & C8V1.0S21+K25 & 675 & 720 & 1000 & ---- \\
H10 & C8V1.0S25+N & 900 & 720 & 1000 & 90 \\
H61 & C8V1.0S25+K10 & 810 & 720 & 1000 & 135 \\
H62 & C8V1.0S25+K15 & 765 & 720 & 1000 & 180 \\
H63 & C8V1.0S25+K20 & 720 & 720 & 1000 & 225 \\
H64 & C8V1.0S25+K25 & 675 & 720 & \\
\hline
\end{tabular}

Description: mix number in the symbolic meaning is as follows:C--said the slurry; 8--aid the water cement ratio of cement slurry, which is $0.8 \mathrm{~W} / \mathrm{C}$; V1.0--said water volume is 1.0 times the size of the slurry; S--sodium silicate; 21 , 25--says of sodium silicate baume degree, namely ${ }^{0}$ Bé 21 , 25, respectively; N--said not adding admixtures, admixture, etc; F--slag powder admixture; 10, 15, 20, 25—said dosage of slag powder or replaced by 10\%, 15\%, 20\%, 25\% cement.

Table 3 Gel time of the double fluid grouting material that add admixture

\begin{tabular}{llllll}
\hline $\begin{array}{l}\text { The ratio of the } \\
\text { serial number }\end{array}$ & The ratio of number & $\begin{array}{l}\text { Gel time t } \\
\text { (s) }\end{array}$ & $\begin{array}{l}\text { The ratio of the } \\
\text { serial number }\end{array}$ & The ratio of number & $\begin{array}{l}\text { Gel time t } \\
(\mathrm{s})\end{array}$ \\
\hline H09 & C8V1.0S21+N & 50 & H10 & C8V1.0S25+N & 52 \\
H57 & C8V1.0S21+K10 & 74 & H61 & C8V1.0S25+K10 & 41 \\
H58 & C8V1.0S21+K15 & 82 & H62 & C8V1.0S25+K15 & 47 \\
H59 & C8V1.0S21+K20 & 108 & H63 & C8V1.0S25+K20 & 46 \\
H60 & C8V1.0S21+K25 & 106 & H64 & C8V1.0S25+K25 & 76 \\
\hline
\end{tabular}

Table 4 Consolidation strength of double fluid grouting material that add admixture

\begin{tabular}{llllll}
\hline \multirow{2}{*}{$\begin{array}{l}\text { The ratio of } \\
\text { the serial } \\
\text { number }\end{array}$} & \multirow{2}{*}{$\begin{array}{l}\text { The ratio of } \\
\text { number }\end{array}$} & \multicolumn{3}{l}{ 7d consolidation strength (MPa) } & \multicolumn{2}{l}{ 28d consolidation strength (MPa) } \\
\cline { 3 - 6 } & $\begin{array}{l}\text { Flexural } \\
\text { strength }\end{array}$ & $\begin{array}{l}\text { Compressive } \\
\text { strength }\end{array}$ & $\begin{array}{l}\text { Flexural } \\
\text { strength }\end{array}$ & $\begin{array}{l}\text { Compressive } \\
\text { strength }\end{array}$ \\
\hline H09 & C8V1.0S21+N & 0.59 & 3.2 & 0.66 & 5.1 \\
H57 & C8V1.0S21+K10 & 0.56 & 3.4 & 0.92 & 3.9 \\
H58 & C8V1.0S21+K15 & 0.59 & 2.9 & 0.80 & 4.7 \\
H59 & C8V1.0S21+K20 & 0.60 & 4.8 & 1.02 & 5.2 \\
H60 & C8V1.0S21+K25 & 0.37 & 2.8 & 0.87 & 4.6 \\
H10 & C8V1.0S25+N & 0.60 & 3.3 & 0.87 & 5.1 \\
H61 & C8V1.0S25+K10 & 0.45 & 3.0 & 0.88 & 4.1 \\
H62 & C8V1.0S25+K15 & 0.52 & 2.8 & 0.82 & 5.2 \\
H63 & C8V1.0S25+K20 & 0.56 & 3.0 & 0.64 & 7.3 \\
H64 & C8V1.0S25+K25 & 0.48 & 2.9 & 0.89 & 5.9 \\
\hline
\end{tabular}

\section{Data Analysis}

C-S Double Liquid Grouting Material Gel Time Analysis. According to table 3 of double liquid grouting material in slag powder gel time of experimental data, can be made in the water to cement ratio and sodium silicate slurry baume degree certain cases, the slag powder content of double liquid grouting material gel time influence diagram(Fig.1).

Fig. 1 the analysis: when the cement slurry water cement ratio is certain, with the increasing content of slag powder, the baume degree ${ }^{0}$ Bé for two kinds of sodium silicate grout in 21 and 25, the influence law of double liquid grouting material prepared by gel time consistent, i.e., with the increase of the amount of slag powder gel time showed a rising trend is relatively stable; but the content of slag powder under the same circumstances, baume degree ${ }^{0}$ Bé 21 than ${ }^{0}$ Bé for double 
liquid grouting material gel time of sodium silicate slurry prepared by 25 general high.

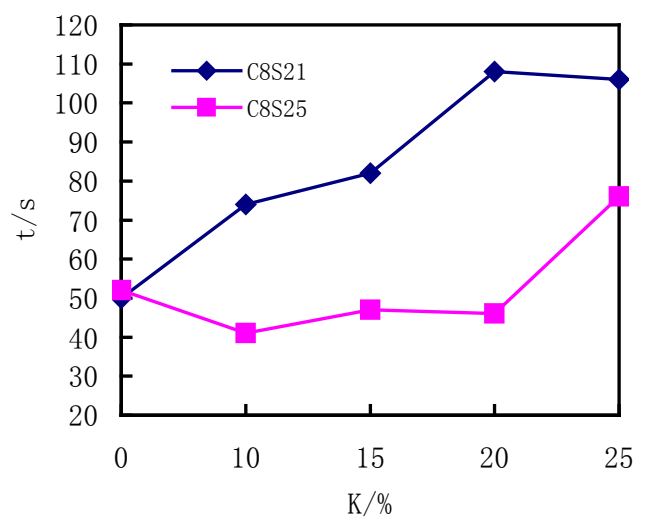

Fig.1 Influence of slag powder on gel time

Analysis of Consolidation Strength of C-S Double Liquid Grouting Material. According to the experimental data in Table 4 consolidation strength, analysts can make the content of slag powder diagram flexural strength, compressive strength of grouting material influence $7 \mathrm{~d}$ and $28 \mathrm{~d}$ (Fig.2).

Fig.2 the analysis: when the water cement ratio and sodium silicate grout slurry baume degree is certain, content of slag powder to produce fluctuations on the impact of consolidation body flexural strength, impact on the compressive strength is stable, has improved stability. Concretion in figure a double liquid grouting material for the 7 day flexural strength, with the first stable basically showed a downward trend after the increase of the amount of slag powder; sodium silicate grout two baume degree b graph, double solution grouting concretion body in the preparation of the 7 day compressive strength with the content of slag powder the increase is basically stable changes, but the sodium silicate baume degree ${ }^{0}$ Bé for double liquid grouting material compressive strength of 21 appeared maximum; concretion in figure c double liquid grouting material for the 28 day flexural strength with the influence of slag powder content fluctuated greatly, the flexural strength of sodium silicate as the material of 21 baume degree ${ }^{0}$ Bé double liquid grouting was larger than sodium silicate baume degree ${ }^{0}$ Bé 25 ; concretion in figure d double liquid grouting material of the 28 day compressive strength with the increase of content of slag powder is relatively stable trend, firm in have litre, when the content of slag powder is large decline trend.

The analysis of the phenomenon, as a result of slag powder into cement slurry, is equivalent to reducing the content of $\mathrm{C}_{3} \mathrm{~S} 、 \mathrm{C}_{2} \mathrm{~S}$ in cement clinker, and slag powder, replacing part of the cement, can save the free water to some degree in hydration, reduced by calcium hydroxide in cement hydration products quantity, have a certain inhibitory effect on procoagulant curing effect sodium silicate grout; the activity $\mathrm{SiO}_{2}, \mathrm{Al}_{2} \mathrm{O}_{3}$ introduced by slag powder can react with calcium hydroxide and water, and produce gel products, so the slag powder has a comprehensive influence on the early strength of double liquid grouting materials, along with the age growth, water consumption and loss, the late consolidation body get enough development, but the uniformity of problems of grouting material in the sample led to the later flexural strength are fluctuated.

\section{Conclusion and Prospect}

Through the determination and comparison analysis of C-S double liquid grouting material of gel time and consolidation strength, what can be clearly found is that through the admixture of adjusting slag powder, the gel time of C-S double liquid grouting material increases efficiently, which affects flexural strength of concretion body while compressive strength is stable relatively, the study also found that the amount of slag powder with relatively stable performance is $15 \%$ $20 \%$. 

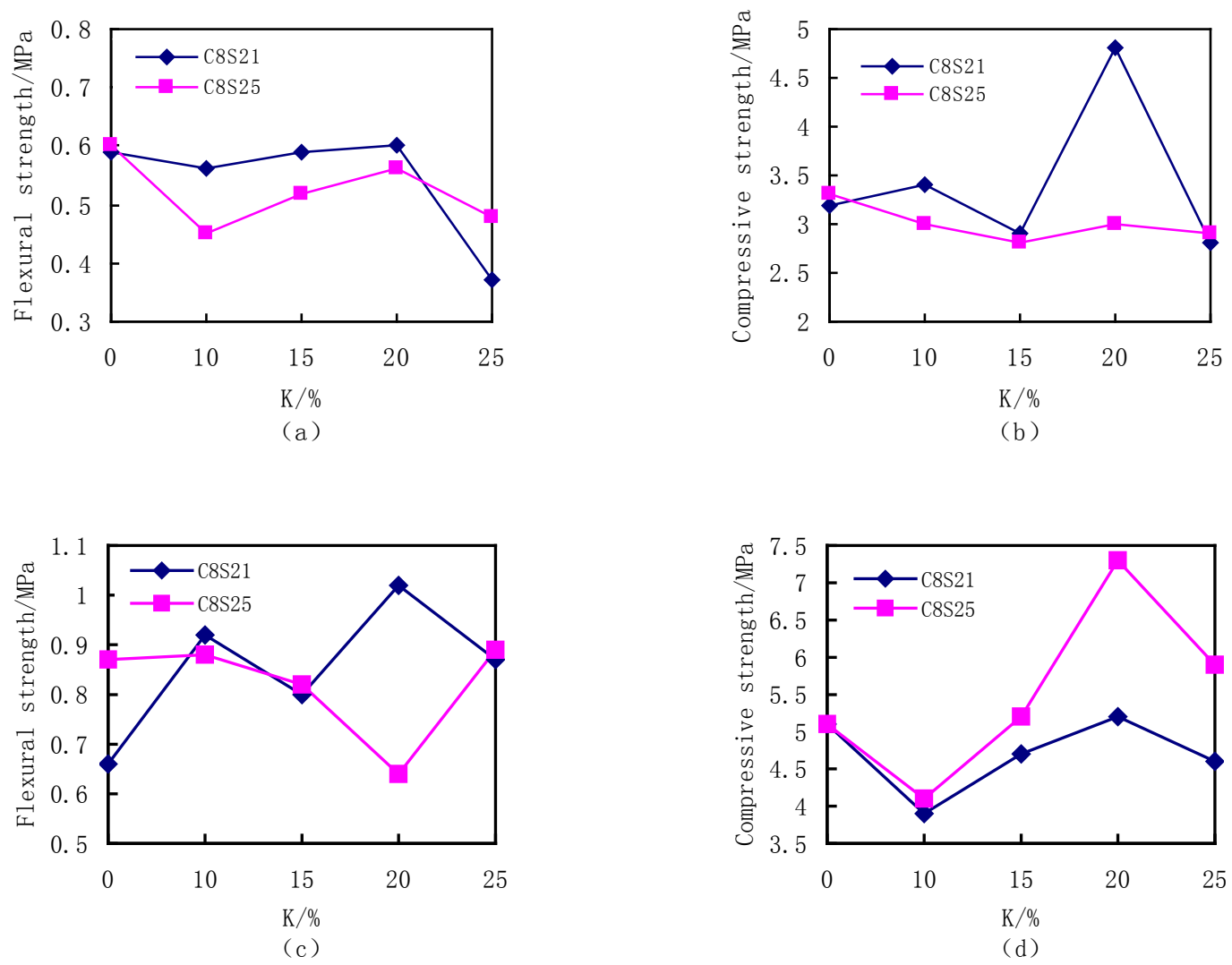

a: 7d bending; b: 7d compressive; c: 28d bending; d:28 d compressive

Fig.2 Influence of slag powder dosage on the consolidation strength

\section{Acknowledgements}

The experimental study from the Zhangjiakou Municipal Science and Technology Bureau and the seismic research project (1321011B).

\section{References}

[1] JGJ/T 211-2010, Grouting technology of double fluid regulation engineering of cement-sodium silicate building[S].

[2] GB 50025-2004, Building standard in collapsible loses plateau[S].

[3] HG/T 20691-2006, Technical regulations of high pressure jet grouting construction operation [S].

[4] X.J. Xue: Brief discussion on treatment of collapsible loess foundation[J]. Chinese western science and technology(2010).

[5] Q. Y. Gao, Buidling Materials[M]. The fourth edition, Wuhan: Wuhan University of Technology Press(2012). 